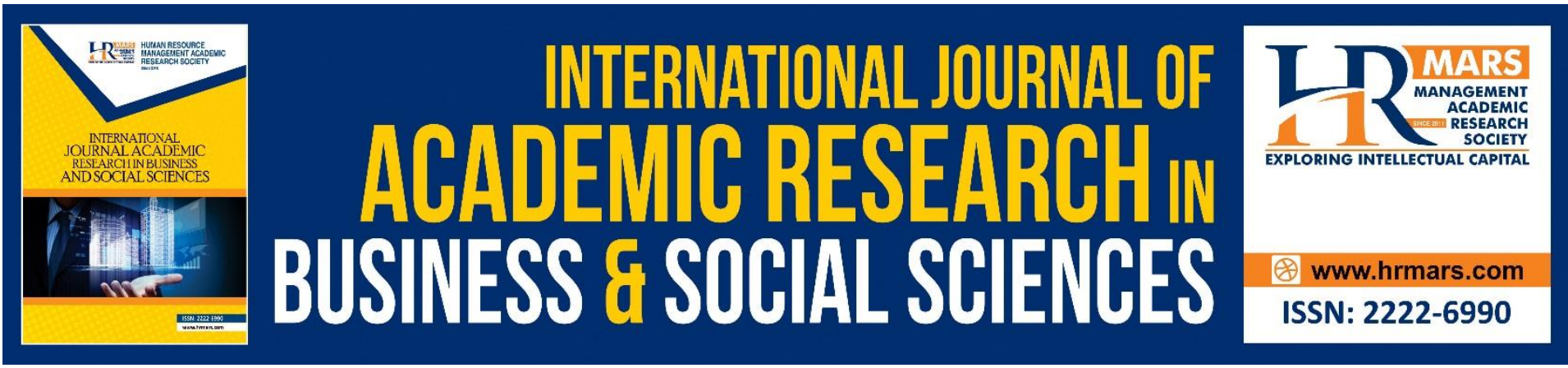

\title{
Influence of Merit Selection Criteria on Private Sector Participation in Provision of Quality Education in Elgeyo- Marakwet County
}

Ann Kiprotich, Kapkiai Moses, Julia Situma

To Link this Article: http://dx.doi.org/10.6007/IJARBSS/v9-i6/5928

DOI: $10.6007 /$ IJARBSS/v9-i6/5928

Received: 02 April 2019, Revised: 17 May 2019, Accepted: 01 June 2019

Published Online: 29 June 2019

In-Text Citation: (Kiprotich, Moses, \& Situma, 2019)

To Cite this Article: Kiprotich, A., Moses, K., \& Situma, J. (2019). Influence of Merit Selection Criteria on Private Sector Participation in Provision of Quality Education in Elgeyo-Marakwet County. International Journal of Academic Research in Business and Social Sciences, 9(6), 125-134.

Copyright: () 2019 The Author(s)

Published by Human Resource Management Academic Research Society (www.hrmars.com)

This article is published under the Creative Commons Attribution (CC BY 4.0) license. Anyone may reproduce, distribute, translate and create derivative works of this article (for both commercial and non-commercial purposes), subject to full attribution to the original publication and authors. The full terms of this license may be seen at: http://creativecommons.org/licences/by/4.0/legalcode

Vol. 9, No. 6, 2019, Pg. 125 - 134

Full Terms \& Conditions of access and use can be found at http://hrmars.com/index.php/pages/detail/publication-ethics 


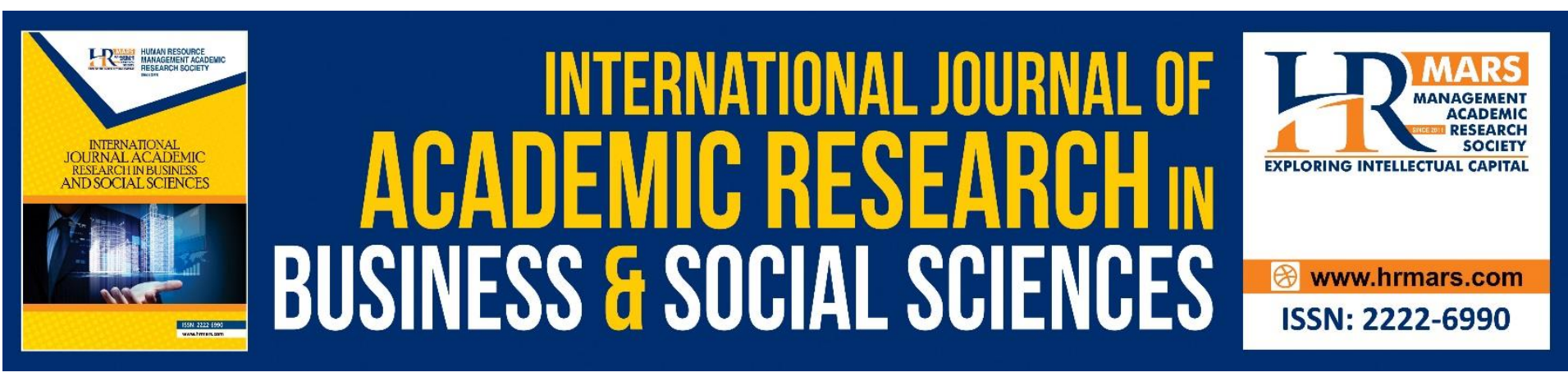

\title{
Influence of Merit Selection Criteria on Private Sector Participation in Provision of Quality Education in Elgeyo-Marakwet County
}

\section{Ann Kiprotich}

Masters student, Kisii university Eldoret campus, Kenya, annsrotich@yahoo.com

\author{
Dr. Kapkiai Moses, Phd, Dr. Julia Situma, Phd
}

Lecturer, School of Education and Human Resource Development, Kisii University

\begin{abstract}
The purpose of this study was to analyze the influence of merit selection criteria on private sector participation in provision of quality education in Elgeyo-Marakwet County. The study was carried out in private primary schools and public secondary schools within Elgeyo-Marakwet County, Kenya. This study used descriptive survey design. Specifically the study targeted secondary school principals, deputy principals, senior teachers and head teachers of private primary schools. After stratifying the secondary schools, then proportionate simple random sampling was applied to each stratum by applying the $30 \%$ principle. This study used questionnaires and interview schedule as instruments for data collection. Data was analyzed using descriptive statistics such as percentage and frequencies. Qualitative data from the interview schedule was analyzed using content analysis technique. Data was presented in form of frequency distribution tables figures. This study found out that merit as criteria of form one selection has enabled private schools post majority of their pupils to national and extra county schools. Despite merit selection in form one, the number of national schools is still low compared to number of candidates who do well in KCPE and deserve to be selected to join these schools. The study recommended that the form oneselection criteria should be based on merit as the main criteria in selection.
\end{abstract}

Keywords: Merit Selection Criteria, Private Sector, Participation, Quality Education 
INTERNATIONAL JOURNAL OF ACADEMIC RESEARCH IN BUSINESS AND SOCIAL SCIENCES Vol. 9, No. 6, June, 2019, E-ISSN: 2222-6990 @ 2019 HRMARS

\section{Introduction}

Education is imperative in the improvement of a nation. It enhances the economy of a nation and to decrease poverty. This thought on the significance of education is upheld by World Bank (2002) which declares that education decreases destitution by creating beneficial aptitudes of the nationals and furnishing individuals with the abilities they have to completely take part in the economy and society. It is under this view the Kenyan government acquainted mandatory fundamental education with enhance the economy, make proficient confident natives and enhance the strength of the public.

Internationally different nations have partitioned arrangement of instruction into esteemed educational systems and less lofty schools. Lofty educational systems are the minority containing 14 for every penny of the aggregate training arrangements relying upon the nation. World class schools frameworks are likewise alluded to particular instruction framework and choice depends on extremely aggressive selection tests, for example in Singapore, grade school leaving examination (PSLE) and in England, 11 or more placement test (Amburo, 2011; Coldron et al., 2010; Yakaboski and Nolan, 2011), in Kenya, the Kenya Certificate of Primary Education (KCPE) examination good grades just to give some examples. Specific training frameworks are viewed as advantaged establishments for most capable or scholarly students or students (Burgess, Greaves, Vignoles \& Wilson, 2014).

In Malawi, the determination foundation is merit-based and PSLCE it is utilized by the service of education to guarantee that the best performers can go to the best level auxiliary school (Conventional optional school) (De Hoop, 2010). Determination into open optional schools depends on legitimacy and therefore there is a cut-off point. Other than in Malawi, a dominant part of different nations on the planet over use examinations as a methods for setting students onto their next dimension of education including elite schools, nonetheless, the criteria for choice to form one may change starting with one nation then to the next.

The Kenyan current education system is one that takes examinations following eight years in essential education, which decides the sort of school a hopeful is conceded into at secondary level. Private sector interest in education participation in the Kenya certificate of primary education (KCPE) which is tested at standard eight decides the change into various kinds of secondary schools in Kenya (Kinyua, 2014). Priscillah (2011) perceives this and notes that KCPE is utilized to choose structure one students to different units of optional schools on the reason that their sterling execution segment interest in education arrangement at KCPE will empower them to perform well at the Kenya certificate of secondary education (KCSE) which comes toward the end of Secondary education.

The end stage national examinations are generally observed as prescient of private sector participation in education provision. Consequently, examinations are an inevitable an integral part of education process. In addition to other things, examinations are utilized to qualify an applicant's dimensions of education, preparing and work (Priscillah, 2011). The Kenya Ministry of Education utilizes a legitimacy based choice framework. With this framework, the Ministry of Education guarantees that the best performers on the KCPE can go to the best secondary schools (National secondary school). Therefore, the researcher sought to find out how form one selection criteria influence private sector participation in education provision in Elgeyo-Marakwet County 


\section{Statement of the Problem}

Despite the Kenyan government increasing, the numbers of candidates who sit for KCPE outweigh them. Merit is one of criteria to select pupils who join these few and competitive schools. Two separate formula based on sub county quota is used to determine the number of candidate from both public primary schools and private academies to be placed in national schools. It is emerging that a number of parents especially from private schools complain that even though their children have scored high marks in KCPE examination, they are selected to low-level and poorly equipped schools, while pupils from public schools with lower marks are selected to better resource national secondary schools. The Kenya Private Schools Association has questioned this parameter and observes that the private primary schools are now facing discrimination on account of the category of schools that their children attended. This raises a question that; is the private sector satisfied with the selection criteria in terms of access to quality education to warrant them actively participate? It is on this background that this study seeks to analyze influence of merit selection criteria on private sector participation in provision of quality education in Elgeyo-Marakwet County.

\section{Literature Review}

Currently, Kenya works four various leveled dimensions of secondary schools to be specific National, Extra-County, County and Sub-county schools, when the present national schools development updating program is finished. There are differentiating contrasts between them as far as educators, offices and different materials or resources (Makori \& Onderi, 2013).

For determination into Form 1 of national all-inclusive schools, students are stratified by gender and after that chose dependent on legitimacy. Since students are chosen into boarding traditional school as per merit there is a cutoff point for choice into boarding customary school versus choice into day regular school. Instead of conveying the constrained assets accessible for secondary education consistently crosswise over schools, numerous legislatures distribute a moderately substantial offer of the accessible assets to a select number of secondary schools. Admission to these schools is normally merit put together and decided with respect to the premise of a test (De Hoop, 2010).

According to the Standard (14 ${ }^{\text {th }}$ March 2014) admission was based on among others merit pupils with as low as $\mathbf{2 5 0}$ marks were admitted to national schools at the expense of those with $\mathbf{4 0 0}$ marks and above from private schools. De Hoop (2010) noted that since the quantity of elementary school graduates outperforms the quantity of accessible spots out in the open secondary schools the Ministry of Education utilizes a legitimacy based choice framework that utilizes Private Sector Participation in Education Provision on the PSLCE as a choice rule. With this framework, the service of education guarantees that the best entertainers on the PSLCE can go to the best secondary schools.

According to Chan, (2008) Admission to gifted education program is strictly based on and the program provides training to the top 1 per cent of students aged 9 to 16 (Nee, 2004). Talented people are identified and or selected through a process of meritocracy and then developed (Barr, 2006 as cited in Sim, 2012): Identify the talented in schools, pump all your resources into nurturing them, exploring their minds to an ever-steeper hierarchy of challenges and then select the best. Schneider and Buckley (2002) study reported that parents value proximity highly and preferences for school performance increase with student income and own academic ability. 
INTERNATIONAL JOURNAL OF ACADEMIC RESEARCH IN BUSINESS AND SOCIAL SCIENCES

Vol. 9, No. 6, June, 2019, E-ISSN: 2222-6990 @ 2019 HRMARS

\section{Research Methodology}

The study was conducted in Elgeyo-Marakwet County. Marakwet East, Marakwet West, Keiyo South and Keiyo North are the four sub counties in this county. This is one of the 47-Counties in Kenya. This study used descriptive survey design to investigate the influence of form one-selection criteria on private sector participation in education provision. Descriptive survey design is utilized in preliminary and exploratory examinations (Luck and Ruben, 2002) to enable researchers to assemble data, analyze, present and interpret with the end goal of clarification. The study targeted various stakeholders in the education sector within the County. Specifically the study targeted secondary school principals, deputy principals, senior teachers and head teachers of private primary schools. This represented 121 secondary school principals, 62 head teachers of private primary schools, 121 deputy principal and 121 senior teachers in Elgeyo-Marakwet County. The sample in the study was generated using probability sampling approach. Probability sampling (stratified sampling) was applied since the 121 secondary schools were stratified into National, Extra-County, County and Mixed day secondary schools. This made sure respondents are found from each category of the schools. After stratifying the schools, then proportionate simple random sampling was applied to each stratum by applying the 30\% principle (Mugenda and Mugenda, 2013). For the private primary schools, those which have registered and sat for K.C.P.E were chosen. The researcher sampled 36 secondary schools Principals (public), 36 deputy principals and 36 senior secondary school teachers and 19 head teachers of private primary schools, adding up to 127 respondents. This study used questionnaires and interview schedule as tools for data collection. The study sought to establish content validity which was utilized to demonstrate whether the test items represented the content that the test was intended to gauge (Mugenda \& Mugenda, 2009). So as to guarantee that every one of the items utilized in the surveys are steady and valid, the instruments were subjected to scrutiny and review by experts of Kisii University more specifically the supervisors. The items were rephrased and modified as per the advice of the supervisors to avoid ambiguity before being used for data collection.

Kombo and Tromp (2006) characterized reliability as a proportion of how steady the outcomes from a test are. An instrument is dependable when it can quantify a variable precisely and reliably and get similar outcomes under similar conditions over a time of time. The researcher utilized the internal consistency to check the reliability of the exploration instruments. This was done by computing the Cronbach's alpha coefficient for every one of the segments of the questionnaire from the results of the pilot study. To do this the reliability of the instrument (survey) the split-half technique was connected. For this study a statistic of 0.7 was realized and this was adequate enough to deem the instrument reliable. Data was analyzed using descriptive statistics such as percentage and frequencies. The findings were presented in form of tables, bar graphs and pie charts.

\section{Findings and Discussion}

\section{Background Information of Respondents}

The researcher sought to establish the gender, age, highest academic qualification, duration in the school, size of the school you are currently heading, quality of education standards. The data on background information has been presented below. 
INTERNATIONAL JOURNAL OF ACADEMIC RESEARCH IN BUSINESS AND SOCIAL SCIENCES

Vol. 9, No. 6, June, 2019, E-ISSN: 2222-6990 (C) 2019 HRMARS

\section{Gender of the respondents}

The researcher sought to establish the gender distribution of respondents in Elgeyo-Marakwet County. The findings are summarized in figure 4.1 .

Figure 4.1: Gender Distribution of Respondents

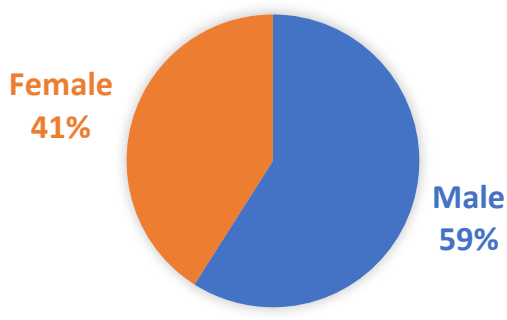

Table 4.1: Gender of Secondary Schools Principals (Public)

\begin{tabular}{lll}
\hline Gender & Frequency & Percentage \\
\hline Female & 45 & 41 \\
Male & 63 & 56 \\
Total & $\mathbf{1 0 8}$ & $\mathbf{1 0 0}$ \\
\hline
\end{tabular}

Figure 4.1 and table 4.1 shows $45(41 \%)$ were female and 63(56\%) were male. From the results majority of respondents were male revealing there is gender disparity in the education sector. The variation of male and female was close hence it is an indication that both genders have embraced leadership positions. It is clear that the Kenyan government has tried to close the gap of gender disparity but more male still participate in form one selection criteria.

\section{Age Bracket of the Respondents}

The researcher sought to find out the age bracket of the respondents in the study. The age bracket will show old the respondent is to be knowledgeable on influence of form one selection criteria on private sector participation in education provision The findings are summarized in table 4.2 and figure 4.2

Table 4.2: Age Bracket of the Respondents

\begin{tabular}{lll}
\hline Age & Frequency & Percentage \\
\hline $26-30$ years & 5 & 5 \\
$31-35$ years & 14 & 15 \\
$36-40$ years & 39 & 34 \\
Over 40 years & 51 & 46 \\
Total & 108 & 100 \\
\hline
\end{tabular}


Figure 4.2: Age bracket of the respondents

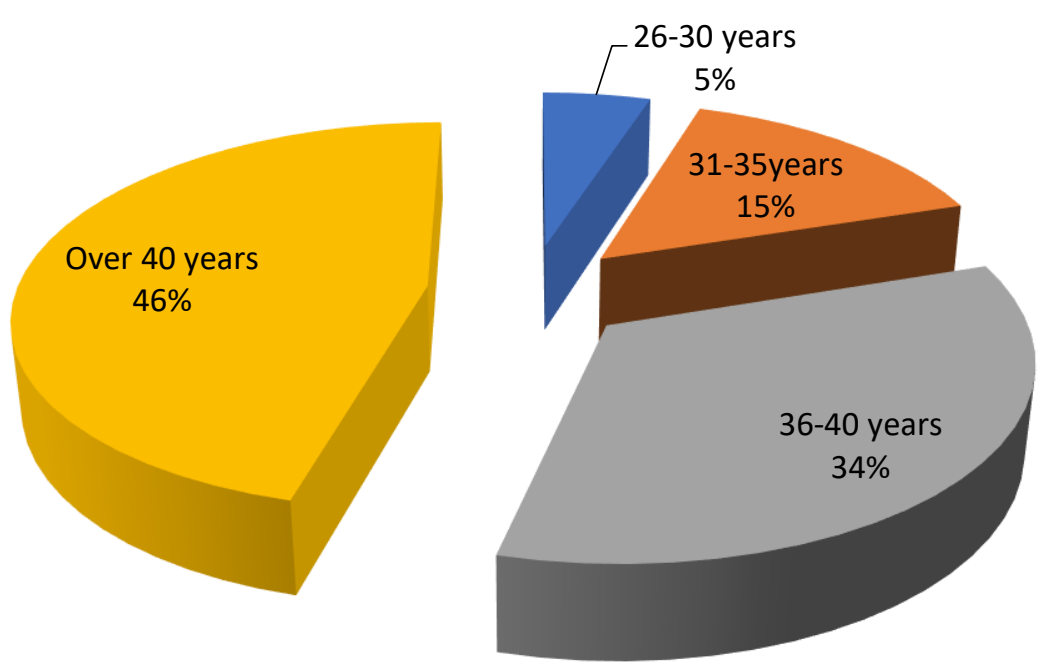

Table 4.2 and figure 4.2 shows $5(5 \%)$ were $26-30$ years, $14(15 \%)$ were $31-35$ years, 39(34\%) were between $36-40$ years, $51(46 \%)$ were over 40 years. From the findings majority of principals' age were over 40-year sampling they had enough experience hence understand form one selection criteria.

\section{Academic Qualification of the Respondents}

The researcher sought to investigate the academic qualification of the respondents in the study. The findings are summarized in table 4.3 and figure 4.3

Table 4.3 Academic Qualification of the Respondents

\begin{tabular}{lll}
\hline Academic qualification & Frequency & Percentage \\
\hline Diploma & 15 & 13 \\
Bachelors & 48 & 45 \\
Master's Degree & 45 & 42 \\
Total & $\mathbf{1 0 8}$ & $\mathbf{1 0 0}$ \\
\hline
\end{tabular}

Figure 4.3: Academic Qualification of the Respondents

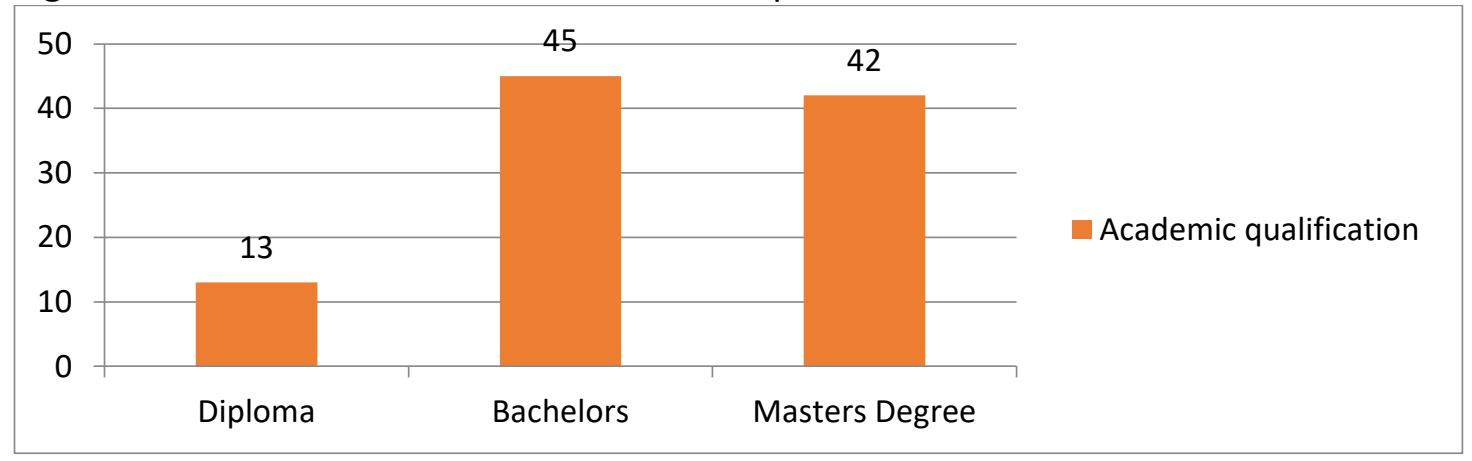


INTERNATIONAL JOURNAL OF ACADEMIC RESEARCH IN BUSINESS AND SOCIAL SCIENCES Vol. 9, No. 6, June, 2019, E-ISSN: 2222-6990 @ 2019 HRMARS

Table 4.3 and figure 4.3 indicates 15(13\%) had diploma, 48(45\%) had reached bachelors level and the remaining had 45(42\%) master's Degree level. From the results it indicates majority of respondents had bachelor's Degree. The research findings show that most of the principals, deputy principals and senior teachers are well educated.

Influence of merit selection criteria on private sector participation in provision of quality education The first objective sought to investigate influence of merit selection criteria on private sector participation in provision of quality education. The findings are summarized in table 4.5.

Table 4.5 Influence of merit selection criteria on private sector participation in provision of quality education

\begin{tabular}{llllll}
\hline MERIT SELECTION CRITERIA & SA & A & N & D & SD \\
\hline $\begin{array}{l}\text { The use of merit based in form one } \\
\text { selection is most preferred by private } \\
\text { sectors }\end{array}$ & $32(60 \%)$ & $11(10 \%)$ & $0(0.0 \%)$ & $0(0.0 \%)$ \\
$\begin{array}{l}\text { The use of merit based in form one } \\
\text { selection has enabled the private }\end{array}$ & & & & \\
sector invest financial resources in \\
education
\end{tabular}

The study findings show that majority of the respondent, 65(60\%) of the principal, deputy principal, senior teachers strongly agreed that the use of merit based in form one selection is most preferred by private sectors, education providers, $32(30 \%)$ agreed and the remaining $11(10 \%)$ were undecided.

On the other hand, $40(37 \%)$ of the respondent strongly agreed that the use of merit based in form selection has enabled the private sector invest financial resources in education, 60(56\%) agreed and the remaining $8(7 \%)$ were neutral. Moreover, $65(60 \%)$ of the respondent strongly agreed that the use of merit based in form selection has enabled the private sector invest human resources in education, $28(26 \%)$ agreed and the remaining $15(14 \%)$ were neutral. The finding further shows that $64(59 \%)$ of the respondents agreed that the use of merit based in form selection has enabled the 
private sector improve access to education, 40(37\%) agreed and the remaining 4(4\%) were neutral. The finding further shows that $76(70 \%)$ of the respondents agreed that the use of merit based in form selection has enabled the private sector share education cost with the government and the remaining $32(30 \%)$ agreed. Finally, 40(37\%) of the respondent strongly agreed that the use of merit based in form one selection has enabled the private sector improve access to education, 60(56\%) agreed and the remaining $8(7 \%)$ were neutral.

Majority of the respondents were in agreement that the use of merit based in form selection has enabled the private sector invest human resources in education and that the use of merit based in form selection has enabled the private sector improve access to education. This is in agreement with De Hoop (2010) who noted that because the number of primary school pupils who seat KCPE are more than available places in public secondary schools hence there is need for merit based selection system to select form ones. By using merit in selection, ensures the top performing students in KCPE are selected to attend the top secondary schools (national and extra county schools).

This was also in opinion with Chan (2008) who stated that admission to gifted education program is strictly based on merit and the program provides training to the top one per cent of students aged 9 to 16 (Nee, 2004). Talented people are identified and or selected through a process of meritocracy and then developed. Nee (2004) identify the talented in schools; pump all your resources into nurturing them, exploring their minds to an ever-steeper hierarchy of challenges and then select the best.

The study findings interview schedule indicated that the use of merit based in form one selection is most preferred by private sectors, education providers. This has enabled the private sector to improve access to education. This merit-based selection ensures that the top performers on the KCPE are able to attend the top secondary schools and those who perform poorly join sub county schools.

The study results from interview schedule indicate that few schools are considered to be performing well in KCSE. The same schools are chosen by many pupils in the class during form one selection. These make pupils to lose the opportunity to join the same school because the chosen school picks only a few students based on merit. The others are closed out hence; they have to look for alternative school not of their choice. 


\section{Conclusion and Recommendations}

The study findings show that majority of the respondents, 65(60\%) of the principals, deputy principals, senior teachers strongly agreed that the use of merit based in form one selection is most preferred by private sectors, education providers. Majority of the respondents were in agreement that the use of merit based in form selection has enabled the private sector invest human resources in education and that the use of merit based in form selection has enabled the private sector improve access to education. The study findings from interviews indicated that the use of merit based in form one selection is most preferred by private sectors, education providers. This has enabled the private sector improve access to education. This merit based selection ensures that the top performers on the KCPE are able to attend the top secondary schools.

Therefore, study concluded that, use of merit based in form selection has enabled the private sector invest human resources in education and that the use of merit based in form selection has enabled the private sector improve access to education by allowing many pupils to join national schools. Despite merit selection in form one, the number of national schools is still low compared to number of candidates who do well in KCPE and deserve to be selected to join these schools. This cause dissatisfaction to many parents and perceives that their children are being discriminated. However, based on the findings of this study what private sector perceives to be discriminative towards their children selection criteria is not.

Considering the findings the study made the following recommendations;

The study recommended that the government should ensure equality in education in all categories of secondary schools to the level of national so that all students access quality education in a given school. The study recommended that candidates be given a detailed induction and guidance during the choosing of schools in the registering process. This should involve parents, teachers and students. The study finally recommended that common formula be used to select public and private schools candidates for national schools.

\section{References}

Allen, R., Coldron, J. \& West, A. (2012). The Effect of Changes in Published Secondary School Admissions on Pupil Composition. Journal of Education Policy, 27(3), 349-366.

Amburo, A. P. (2011). Teaching in a Changing Africa: Differential Academic Performance of Students from Academies and Public Primary Schools at KCSE Examination in Kenya. International Journal of Innovative Interdisciplinary Research, 1(1), 68-72.

Makori, A. \& Onderi, H. (2013). An Evaluation of Secondary School Principals' Perception of Learning Resources in Free Secondary Education Era in Kenya. African Educational Research Journal, 1(3), 171-182.

Schneider, M. \& Buckley, J. (2002). What Do Parents Want From Schools? Evidence from the Internet. Educational Evaluation and Policy Analysis, 24(2), 133-144.

Yakaboski, T. \& Nolan, K. (2011). The Kenyan School Systems' Impact on Public Higher Education Access: Examination of Growth, Access, and Challenges. Journal of International Education and Leadership, 1(1), 1-10. 